DOI: $10.6060 / \mathrm{mhc} 191177 \mathrm{~b}$

\title{
X-Ray Diffraction Study of Crystal Structure and Thin Films of Chromium(II) Phthalocyaninate
}

\author{
Aleksandr S. Sukhikh, Darya D. Klyamer, and Tamara V. Basova@ ${ }^{\circledR}$ \\ Nikolaev Institute of Inorganic Chemistry, 630090 Novosibirsk, Russia \\ ${ }^{\circledR}$ Corresponding authorE-mail: basova@niic.nsc.ru
}

Crystal structure of $\mathrm{Cr}(\mathrm{II})$ phthalocyaninate $(\mathrm{CrPc})$ was determined by means of single-crystal X-ray diffraction. It was shown that after vacuum sublimation CrPc crystallized as a $\beta$-polymorph, which was isostructural to $\beta$-polymorphs of other metal phthalocyanines. When deposited onto glass substrate by organic molecular beam deposition, $\mathrm{CrPc}$ formed thin films with strong preferred orientation, consisting of $\alpha$-polymorph. It was shown that both $\beta$-CrPc powder and $\alpha$-CrPc films were unstable in air and transformed to $\mathrm{Cr}(\mathrm{OH}) \mathrm{Pc}$. X-Ray diffraction (XRD) studies showed that $\beta$-CrPc polycrystalline powder after storage in air (relative humidity $20 \%$ ) began to exhibit the first signs of degradation already in 1 hour, while the first changes in XRD patterns of $\alpha$-CrPc films became noticeable only after a few days. Annealing of $\alpha-C r P c$ films at $250{ }^{\circ} \mathrm{C}$ in air at a relative humidity of $70 \%$ leads to their faster conversion to $\mathrm{Cr}(\mathrm{OH}) \mathrm{Pc}$, and the resulting films have a high degree of crystallinity.

Keywords: Chromium phthalocyanine, XRD, single crystal, thin films, 2D GIXD.

\section{Аифрактометрическое исследование кристаллической структуры и тонких пленок фталоцианината хрома(II)}

\author{
А. С. Сухих, А. А. Клямер, Т. В. Басова ${ }^{@}$ \\ Институт неорганической химии им. А.В. Николаева, 630090 Новосибирск, Россия \\ ${ }^{\circledR}$ E-mail: basova@niic.nsc.ru
}

\begin{abstract}
Кристаллическая структура фталочианината хрома(II) (CrPc) была определена методом монокристальной дифракции. Было показано, что после вакуумной сублимации СгРс кристаллизуется в виде $\beta$-полиморфа, который изоструктурен $\beta$-полиморфам фталоцианинатов других металлов. При осаждении на стеклянную подложку методом термического осаждения из газовой фазы СrРс образует тонкие пленки, состоящие из $\alpha$-полиморфа, с сильной преимущественной ориентацией. Было показано, что как поликристаллический порошок $\beta$-CrPc, так и пленки $\alpha$-CrPc нестабильны на воздухе и переходят в $\mathrm{Cr}(\mathrm{OH})$ Pс. Первые изменения в дифрактограммах порошка $\beta$-СrРс становятся заметны уже через час после их контакта с воздухом, в то время как изменения в дифрактограммах пленок $\alpha$-CrPс начинают фиксироваться только через несколько дней. Отжиг пленок $\alpha$-СrРс при $250{ }^{\circ} \mathrm{C}$ на воздухе при относительной влажности $70 \%$ приводит к их более быстрому превращению в $\mathrm{Cr}(\mathrm{OH}) \mathrm{Pc}$, при этом полученные пленки обладают высокой степенью кристалличности.
\end{abstract}

Ключевые слова: Фталоцианинат хрома, рентгеновская дифракция, монокристаллы, тонкие пленки, 2D GIXD. 


\section{Introduction}

Metal phthalocyanines (MPcs) belong to the class of tetrapyrrole complexes and attract the attention of researchers due to their wide applications in catalysis,,${ }^{[1,2]}$ photodynamic therapy, ${ }^{[3]}$ chemical sensing and electrochromic devices. ${ }^{[4,5]}$ Among them chromium phthalocyaninates demonstrate attractive electrochemical behavior and catalytic activity. ${ }^{[6,7]}$ For instance, Obirai et al..$^{[7]}$ have demonstrated the catalytic activity of electrosynthesized chromium tetraaminophthalocyanine towards oxidation of nitric oxide and nitrite.

For the application in most electronic devices phthalocyanines should be deposited as thin films. It is known that the structure of thin films has a significant effect on their properties and characteristics. It was shown that thin films of chromium phthalocyanine $(\mathrm{CrPc})$ could be deposited using vacuum deposition techniques, but they were not stable in air and oxidized to $\mathrm{Cr}(\mathrm{OH}) \mathrm{Pc}{ }^{[8]}$ However, Ercolani et al..$^{[9]}$ reported that $\alpha$-polymorph of $\mathrm{CrPc}$ was stable in air. Since it is well known that other metal phthalocyanines such as $\mathrm{CoPc}^{[10,11]}$ and $\mathrm{ZnPc}{ }^{[12,13]}$ are deposited onto substrate surface as $\alpha$-polymorphs, it is suggested that air stable CrPc thin films can be obtained if $\mathrm{CrPc}$ is deposited onto the substrate surface as $\alpha$-polymorph.

Despite a number of adducts of chromium phthalocyaninates with solvents like tetrahydrofuran and dimethoxyethane, e.g. PcCrI(THF), $\mathrm{PcCrI}_{3}(\mathrm{THF}),\left[\mathrm{PcCr}(\mathrm{THF})_{2}\right] \mathrm{SbF}_{6}$, $\left[\mathrm{K}(\mathrm{DME})_{4}\right]_{2}[\mathrm{PcCr}],\left[\mathrm{K}_{6}(\mathrm{DME})_{4}\right]\left[\mathrm{Pc}_{4} \mathrm{Cr}\right]_{2}$ and etc. ${ }^{[6,14-19]}$ were structurally characterized, the structure of single crystals of unsubstituted $\mathrm{CrPc}$ was not determined so far. For this reason, all previous studies of $\mathrm{CrPc}$ thin films were not supported by single crystal structural data.

Thus, the main goal of this paper was to determine the single crystal structure of $\mathrm{CrPc}$ and study the structural organization, phase composition and air stability of $\mathrm{CrPc}$ thin films using X-ray diffraction techniques.

\section{Experimental}

$\mathrm{CrPc}$ was synthesized according to the procedure described elsewhere. ${ }^{[9]}$ The obtained dark violet powder was crushed in an agate mortar and purified by gradient sublimation in vacuum $\left(10^{-5}\right.$ Torr $)$ at $430{ }^{\circ} \mathrm{C}$ in a glass tube. The resulting product was small needle-shaped crystals with dark violet color and metallic luster, which is typical for metal phthalocyanines. CrPc thin films were deposited by an organic molecular beam deposition technique in vacuum $\left(10^{-5}\right.$ Torr $)$ onto glass substrates. The substrate temperature was $80^{\circ} \mathrm{C}$. The nominal thickness of the films was $150-200 \mathrm{~nm}$. After preparation, all samples (polycrystalline powder, single crystals, thin films) were stored in a desiccator.

Crystal structure of $\mathrm{CrPc}$ was determined at $298 \mathrm{~K}$ using a Bruker X8 Apex single-crystal diffractometer $(\mathrm{MoK} \alpha$ sealed $\mathrm{X}$-ray tube with a graphite monochromator, APEX CCD-detector). APEX3 software package (SAINT, SADABS ${ }^{[20]}$ was used for raw frame collection, data reduction, absorption correction and unit cell refinement. The structure solution was performed in Olex2 1.2.10 $0^{[21]}$ with SHELXT-2018/2 $2^{[22]}$ and SHELXL-2018/3 ${ }^{[23]}$ used for the solution and structure model refinement, respectively. Powder and thin film diffraction patterns were recorded using a Shimadzu XRD-7000 diffractometer (CuK $\alpha$, Bragg-Brentano scheme vertical $\theta-\theta$ goniometer with a scintillation counter detector). Diffraction peak profiles were fitted using the Voigt function.
2D GIXD (GIWAXS) patterns of CrPc thin films were obtained using a Bruker DUO single-crystal diffractometer (Incoatec $I \mu \mathrm{S}_{\mathrm{Cu}}$ $\mathrm{Cu}$-anode microfocus tube, Apex II CCD detector). A thin glass substrate with $\mathrm{CrPc}$ film was placed in the special sample adapter and mounted onto the goniometer head. The primary X-ray beam angle of incidence was about $0.5^{\circ} .2 \theta$ position of the CCD detector was set at $0^{\circ}$; the distance from the sample to the detector was $80 \mathrm{~mm}$.

UV-Vis spectra were recorded using a UV-Vis-3101PC "Shimadzu" spectrophotometer. IR spectra were recorded using a Vertex 80 FTIR spectrometer.

To investigate stability of $\mathrm{CrPc}$ powders and films the samples were heated at different conditions in a glass ampoule that was filled with air or vacuumized. Moist air was prepared by its bubbling through distilled water. The relative humidity (RH) inside the tube was controlled with a commercially available digital humidity meter IT-8.

\section{Results and Discussion}

A reasonably large $(0.3 \mathrm{~mm} \times 0.05 \mathrm{~mm} \times 0.05 \mathrm{~mm}) \mathrm{CrPc}$ single crystal was mounted onto a nylon loop with epoxy resin. Particular attention was paid to ensure that the crystal was completely coated with epoxy resin to prevent its decomposition under the influence of atmospheric moisture. The unit cell parameters and refinement details of a $\mathrm{CrPc}$ single crystal are given in Table 1 . CrPc crystallizes in $P 2_{1} / n$ space group with molecules arranged in the herringbone pattern, which is identical to high-temperature $\beta$-polymorphs of other metal phthalocyanines, e.g. $\beta-\mathrm{CuPc},{ }^{[24]} \beta-\mathrm{CoPc},{ }^{[25]}$ $\beta-\mathrm{ZnPc},{ }^{[26]}$ etc. The packing diagram of $\mathrm{CrPc}$ molecules is shown in Figure 1.

The distance between two molecules in a stack (mean square plane through all non-hydrogen atoms) is $3.349 \AA$,

Table 1. Unit cell parameters and refinement details of a $\mathrm{CrPc}$ single crystal.

\begin{tabular}{|c|c|}
\hline Compound & $\mathrm{CrPc}$ \\
\hline Formula & $\mathrm{C}_{32} \mathrm{H}_{16} \mathrm{~N}_{8} \mathrm{Cr}$ \\
\hline F.W. & 564.53 \\
\hline Temperature, K & 298 \\
\hline Crystal system & monoclinic \\
\hline Space group & $P 2_{1} / n$ \\
\hline$a, \AA$ & $14.6544(14)$ \\
\hline$b, \AA$ & $4.8399(4)$ \\
\hline$c, \AA$ & $17.3324(17)$ \\
\hline$\beta,{ }^{\circ}$ & $105.699(2)$ \\
\hline Volume, $\AA^{3}$ & $1183.46(19)$ \\
\hline Z & 2 \\
\hline$\rho_{\text {calc }}, \mathrm{g} \cdot \mathrm{cm}^{-3}$ & 1.584 \\
\hline GooF & 1.024 \\
\hline $2 \theta$ range for data collection, ${ }^{\circ}$ & $3.24 \div 56.54$ \\
\hline $\begin{array}{l}\text { Data completeness up } \\
\text { to } 50^{\circ} 2 \theta, \%\end{array}$ & 100 \\
\hline$R_{\mathrm{int}}, \%$ & 3.62 \\
\hline$R_{1}, \%$ & 4.37 \\
\hline CCDC No. & 1956459 \\
\hline
\end{tabular}



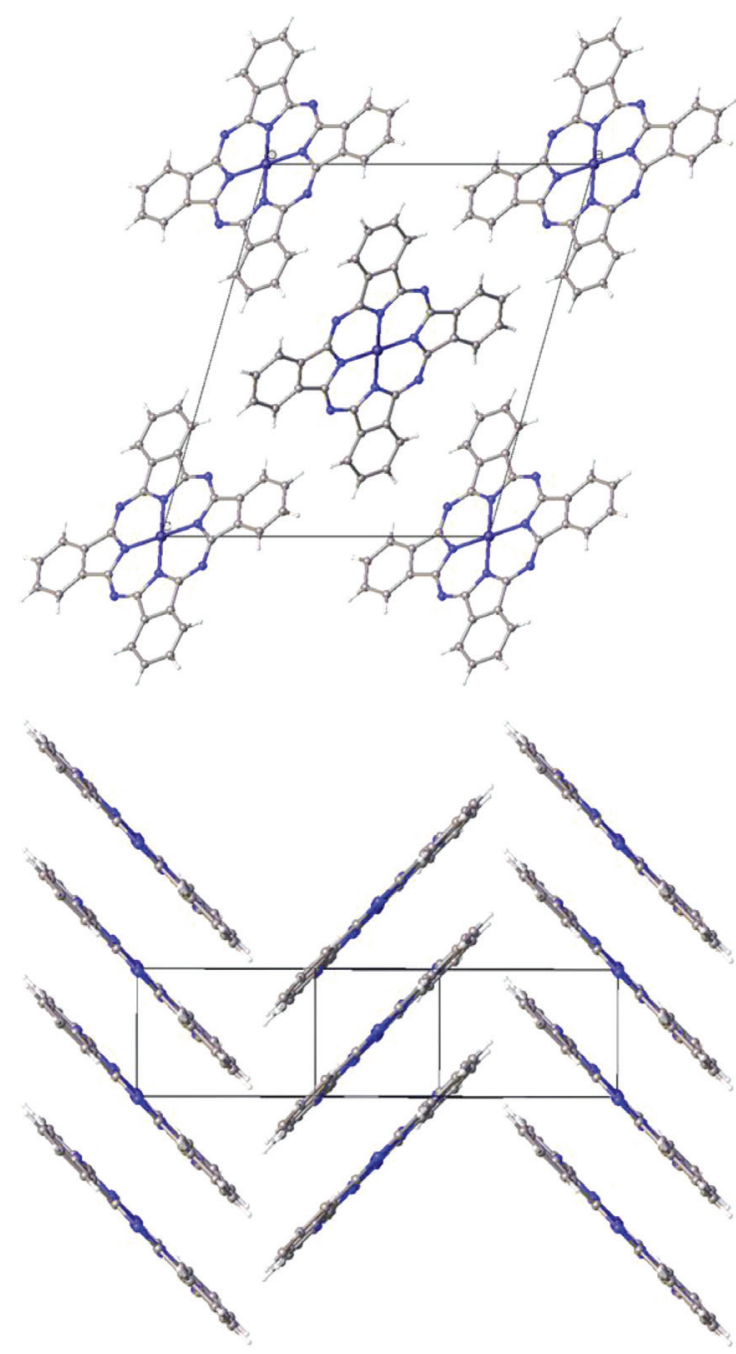

Figure 1. Packing diagram for $\mathrm{CrPc}$ molecules.

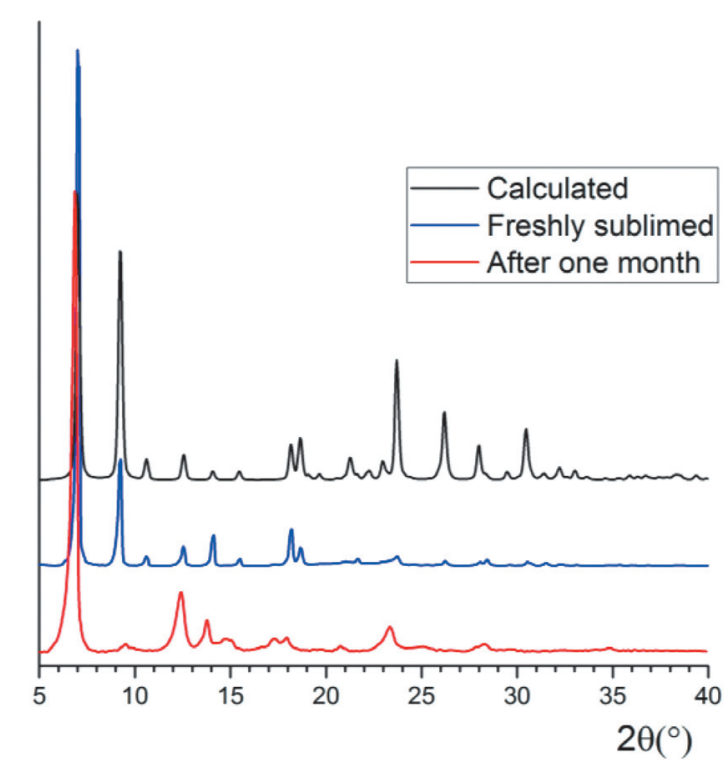

Figure 2. XRD patterns of CrPc: calculated from single-crystal data (black line), for the freshly sublimed powder (blue line) and the powder after storage for a month in air at RH $20 \%$ (red line). while the stacking angle (angle between the stacking direction and the plane of molecule) is $43.78^{\circ}$ for $\mathrm{CrPc}$, which is similar to $\beta$-polymorphs of other metal phthalocyanines: $\operatorname{CuPc}\left(3.342 \AA\right.$ and $\left.44.24^{\circ}\right), \operatorname{CoPc}\left(3.320 \AA\right.$ and $\left.44.07^{\circ}\right)$ and $\mathrm{ZnPc}\left(3.338 \AA\right.$ and $\left.43.45^{\circ}\right)$.

It is worth mentioning that unlike other M(II)Pc $(\mathrm{M}=\mathrm{Cu}, \mathrm{Zn}, \mathrm{Co}, \mathrm{Ni}) \mathrm{CrPc}$ is not stable in air. To investigate stability of $\mathrm{CrPc}$ powders and films the XRD patterns of freshly prepared samples were compared with those after storage in air at RH $20 \%$ for 1 month, after 1 hour annealing at $250{ }^{\circ} \mathrm{C}$ in vacuum $\left(5 \cdot 10^{-5}\right.$ Torr $)$, after 1 hour annealing at $250{ }^{\circ} \mathrm{C}$ in air at $\mathrm{RH} 20 \%$ and after 1 hour annealing at $250{ }^{\circ} \mathrm{C}$ in air at RH $70 \%$.

Figure 2 shows diffraction patterns of the freshly sublimed $\mathrm{CrPc}$ powder and the powder after storage for a month in air (RH $20 \%$ ) in comparison with the pattern calculated from single crystal data. The diffraction pattern of the freshly sublimed CrPc powder is identical to the calculated one, confirming that no other crystal phases are present in the bulk sample. Different relative intensities of diffraction peaks are caused by strong texture of the sample because CrPc crystals are shaped like needles and cannot be grinded in the mortar because of their sensitivity to moisture. X-ray diffraction studies showed that chromium phthalocyanine polycrystalline powder after storage in air (RH $20 \%$ ) for 1 hour already began to exhibit the first signs of degradation. After one week, CrPc completely lost its crystallinity. When observed under a microscope, freshly sublimed CrPc crystals looked like dark violet needles with metallic luster, but after one week they acquired a twisted appearance. However, one more week later the powder started to crystallize slowly to $\mathrm{Cr}(\mathrm{OH}) \mathrm{Pc}$. The diffraction patterns of the $\mathrm{CrPc}$ powder after its storage for a month in air (RH $20 \%$ ) differ from that of freshly sublimed powder, indicating the formation of a different crystalline phase. The measured interplanar distances and relative peak intensities for the powder after storage for a month in air are given in Table 2. According to the data reported by Ercolani et al. ${ }^{[9]}$ this crystalline phase can be identified as $\mathrm{Cr}(\mathrm{OH}) \mathrm{Pc}$.

IR spectroscopy was additionally used to study

Table 2. Measured interplanar distances and relative peak intensities of $\mathrm{Cr}(\mathrm{OH}) \mathrm{Pc}$ XRD pattern.

\begin{tabular}{cc}
\hline $\mathrm{d}_{\text {exp }}(\AA)$ & $\mathrm{I}_{\text {exp }}(\%)$ \\
\hline 12.92 & 100 \\
9.281 & 2.5 \\
7.153 & 21.3 \\
6.434 & 7.2 \\
5.984 & 8.3 \\
5.124 & 5.3 \\
4.943 & 4.0 \\
4.275 & 1.0 \\
3.817 & 8.7 \\
3.560 & 3.4 \\
3.165 & 2.6 \\
3.016 & 0.6 \\
2.579 & 1.0
\end{tabular}




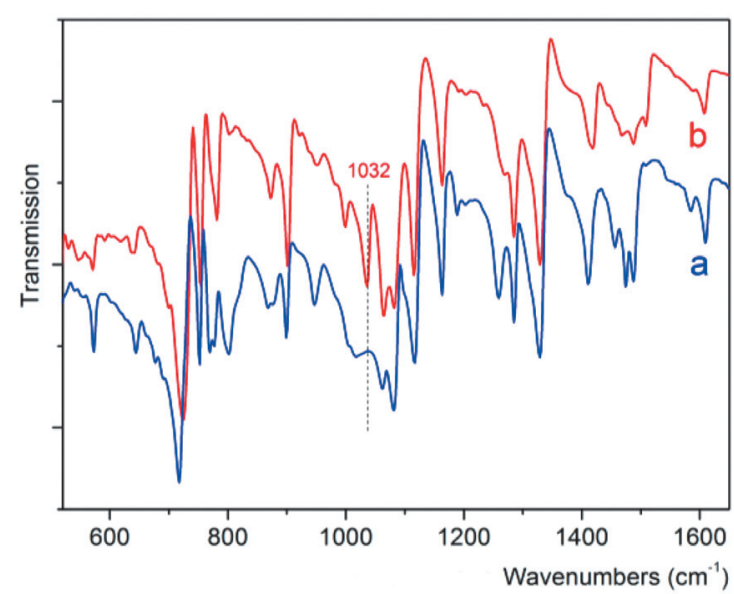

Figure 3. IR spectra of freshly sublimed (a) and stored for a month in air (RH $20 \%$ ) (b) CrPc powders.

the degradation of CrPc powder. IR spectra of freshly sublimed $\mathrm{CrPc}$ powder and the same powder stored for a month in air (RH $20 \%$ ) are shown in Figure 3. The additional comparatively intense band at $1032 \mathrm{~cm}^{-1}$ corresponding to $\mathrm{Cr}-\mathrm{O}$ stretching vibrations appears in the spectrum of $\mathrm{CrPc}$ powder stored for a month in air. Besides, the group of bands at $715-770 \mathrm{~cm}^{-1}$ shifts by $3-7 \mathrm{~cm}^{-1}$ to the higher wavenumbers after the prolonged contact of $\mathrm{CrPc}$ with air moisture. These changes can also be a clear indication of CrPc powder degradation and its transformation to $\mathrm{Cr}(\mathrm{OH}) \mathrm{Pc}$ upon interaction with $\mathrm{H}_{2} \mathrm{O}$ present in the air.

Several XRD patterns of CrPc films are shown in Figure 4. The XRD pattern of CrPc film taken immediately after its deposition contain one strong peak with $\mathrm{d}=12.79 \AA$ and two weak peaks with $\mathrm{d}=6.38 \AA$ and $\mathrm{d}=3.23 \AA$. The absence of other diffraction peaks and the fact that two

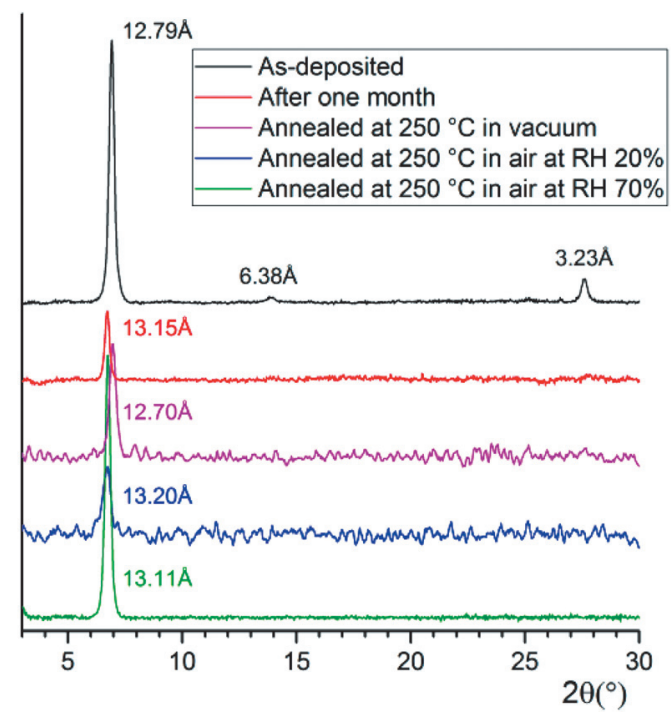

Figure 4. XRD patterns for $\mathrm{CrPc}$ thin films: as-deposited (black line), after storage in air at RH $20 \%$ for 1 month (red line), after 1 hour annealing at $250{ }^{\circ} \mathrm{C}$ in vacuum (magenta line), after 1 hour annealing at $250{ }^{\circ} \mathrm{C}$ in air at RH $20 \%$ (blue line), and after 1 hour annealing at $250{ }^{\circ} \mathrm{C}$ in air at $\mathrm{RH} 70 \%$ (green line). weak peaks have interplanar distances equal to $1 / 2$ and $1 / 4$ of the interplanar distance of the strong peak indicate that the $\mathrm{CrPc}$ film has strong preferred orientation relative to the substrate surface.

After 1 hour annealing at $250{ }^{\circ} \mathrm{C}$ in vacuum $\left(10^{-5}\right.$ mbar) (Figure 4, magenta line) $\mathrm{CrPc}$ thin film does not show any noticeable changes (the diffraction pattern looks more noisy because of the less acquisition time). The interplanar distance of the strongest peak becomes slightly smaller because of the reduced mechanical stress in CrPc crystallites. At the same time, annealing in air at RH $20 \%$ leads to the noticeable changes of the XRD pattern (Figure 4, blue line). After 1 hour annealing at $250{ }^{\circ} \mathrm{C}$ the intensity of the first diffraction peak reduces significantly, while its interplanar distance increases to $13.2 \AA$. This may be due to the transformation of $\mathrm{CrPc}$ to $\mathrm{Cr}(\mathrm{OH}) \mathrm{Pc}$. At the same time, after 1 hour annealing at $250{ }^{\circ} \mathrm{C}$ in air at $\mathrm{RH} 70 \%$ the intensity of the diffraction pattern increases because of the formation of $\mathrm{Cr}(\mathrm{OH}) \mathrm{Pc}$ films with the higher crystallinity. The diffraction peak on its XRD pattern has a slightly less interplanar distance compared to the film annealed in air at RH $20 \%$.

Storage of the film in air (RH $20 \%$ ) at room temperature without heating (Figure 4, red line) also leads to similar changes in the XRD pattern, but the resulted film exhibits the less degree of crystallinity. It is worth mentioning that these changes are much slower than in the case of $\beta$-CrPc powders. The first signs of degradation begin to appear in XRD patterns only in several days.

The XRD data of CrPc thin films are in good agreement with their UV-Vis spectra. The optical absorption spectra of the as-deposited film, the film after 1 hour annealing at $250{ }^{\circ} \mathrm{C}$ in vacuum, after 1 hour annealing at $250{ }^{\circ} \mathrm{C}$ in air at RH $20 \%$ and RH $70 \%$ are given in Figure 5. The as-deposited $\mathrm{CrPc}$ film is characterized by a wide characteristic absorption $Q$-band in the region of $500-800 \mathrm{~nm}$ with the absorption maximum at $640 \mathrm{~nm}$. It is known that the $Q$-band in UV-Vis spectra of phthalocyanine films is sensitive to their structure and phase composition. ${ }^{[27]}$

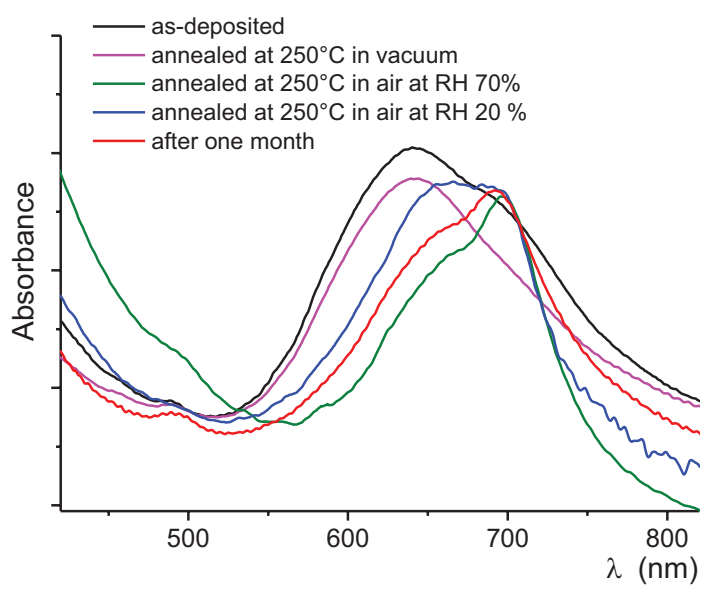

Figure 5. Optical absorption spectra of $\mathrm{CrPc}$ thin films: asdeposited (black line), after storage in air at RH $20 \%$ for 1 month (red line), after 1 hour annealing at $250{ }^{\circ} \mathrm{C}$ in vacuum (red line), after 1 hour annealing at $250{ }^{\circ} \mathrm{C}$ in air at RH $20 \%$ (blue line), and after 1 hour annealing at $250{ }^{\circ} \mathrm{C}$ in air at RH $70 \%$ (green line). 

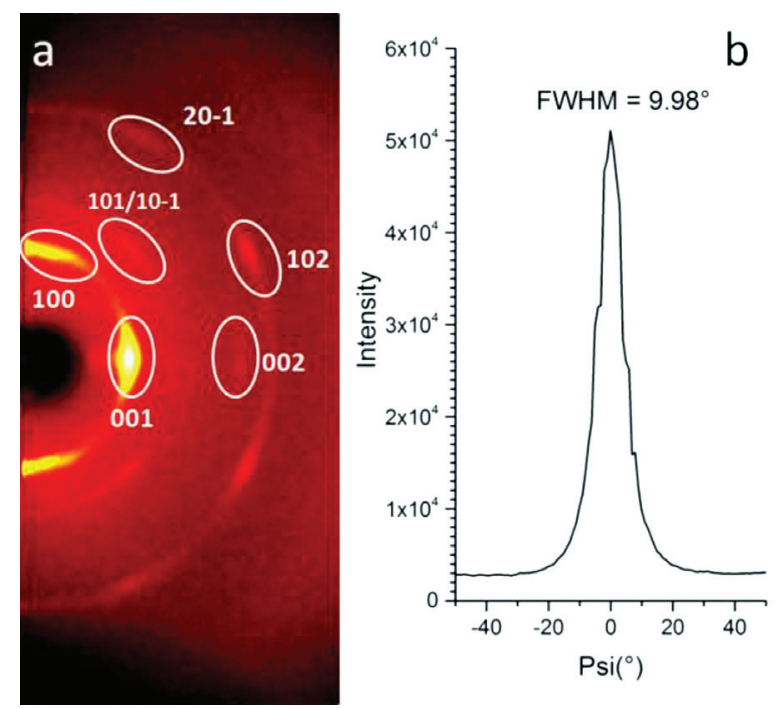

Figure 6. 2D GIXD pattern of as-deposited CrPc thin film (a) and azimuthal profile (phi scan) of the (001) peak (b).

After the film annealing at $250{ }^{\circ} \mathrm{C}$ in vacuum, its spectrum remains almost unchanged. Annealing in air at $250{ }^{\circ} \mathrm{C}$ during 1 hour leads to the shift of the $Q$-band maximum to $696 \mathrm{~nm}$ with the appearance of shoulder at $663 \mathrm{~nm}$. These changes were shown by XRD data to occur due to the formation of $\mathrm{Cr}(\mathrm{OH}) \mathrm{Pc}$. The spectrum of the films annealed at $250{ }^{\circ} \mathrm{C}$ in air at $\mathrm{RH} 20 \%$ corresponds to the mixture of $\mathrm{CrPc}$ and $\mathrm{Cr}(\mathrm{OH}) \mathrm{Pc}$. The spectra of the films after storage in air at RH $20 \%$ for 1 month and after 1 hour annealing at $250{ }^{\circ} \mathrm{C}$ in air at RH $70 \%$ are similar to each other.

It is necessary to mention that the measured interplanar distances of all three peaks observed on the diffraction pattern of as-deposited CrPc film (Figure 4, black line) do not coincide with either those calculated from the single crystal data of $\beta$-CrPc (12.58 $\AA, 6.29 \AA$ and $3.145 \AA)$ or reported by Ercolani et al. ${ }^{[9]}$ for $\alpha-\operatorname{CrPc}(12.55 \AA, 6.30 \AA$ and $3.16 \AA)$. For this reason, it was impossible to determine the phase composition of $\mathrm{CrPc}$ thin film using only conventional XRD data. For this purpose, the as-deposited CrPc thin film was studied using a 2D GIXD technique described in more detail in our previous works. ${ }^{[28,29]}$ The 2D GIXD pattern of as-deposited CrPc film is shown in Figure 6a.

Instead of uniform diffraction rings, the localized diffraction spots are observed in the 2D GIXD pattern, which is typical for oriented thin films. The obtained 2D GIXD pattern does not match the pattern of $\beta$-polymorph of $\mathrm{CrPc}$. For example, $\beta$-CrPc has only one diffraction peak $(10-1)$ in the $2 \theta$ region from 6.5 to $7.5^{\circ}$, while two peaks azimuthally rotated $90^{\circ}$ relative to each other are observed on the 2D GIXD pattern of as-deposited film. This pattern, however, is very similar to 2D GIXD patterns obtained from thin films of $\alpha-\mathrm{CoPc},{ }^{[28]}$ which indicates that the investigated $\mathrm{CrPc}$ film crystallizes as an $\alpha$-polymorph. Therefore, $h k l$ indexes were assigned to the observed diffraction peaks by analogy with $\alpha$-CoPc. Ercolani et al. ${ }^{[9]}$ assigned different $h k l$ indexes to the diffraction pattern of $\alpha-\mathrm{CrPc}$, but since no structure data were available for $\alpha-\mathrm{CrPc}$, it was impossible at that time to say if such indexing was correct.
In order to estimate the degree of preferred orientation of $\mathrm{CrPc}$ thin film, 2D GIXD diffraction pattern was processed in a XRD2Dscan v.4.1.1 program. ${ }^{[30]}$ Figure $6 \mathrm{~b}$ shows the azimuthal scan (phi-scan) of (001) peak, calculated by azimuthal integration in the $2 \theta$ region of $\pm 0.5^{\circ}$ from the (001) peak maximum. FWHM of the (001) peak azimuthal profile is $9.98^{\circ}$. Since the $\mathrm{CrPc}$ film has preferred orientation with the (001) lattice plane parallel to the substrate surface, the azimuthal profile of (001) peak clearly shows the distribution of the angles of inclination of $\mathrm{CrPc}$ crystallites relative to the substrate surface, that in this case varies in the range $\pm 10^{\circ}$ for most of crystallites.

\section{Conclusions}

In this work, crystal structure of $\mathrm{Cr}$ (II) phthalocyaninate was determined by the means of single crystal diffraction for the first time. It was shown that the CrPc powder obtained by sublimation in vacuum consisted of pure $\beta$-polymorph, which was isostructural to $\beta$-polymorphs of other metal phthalocyanines, viz. $\mathrm{CuPc}, \mathrm{CoPc}, \mathrm{ZnPc}$, etc. When deposited onto a glass substrate by OMBD in vacuum, $\mathrm{CrPc}$ formed highly oriented films consisting of $\alpha$-polymorph. It was shown that both $\beta-\mathrm{CrPc}$ powder and $\alpha-\mathrm{CrPc}$ films were unstable in air and transformed to $\mathrm{Cr}(\mathrm{OH}) \mathrm{Pc}$. X-Ray diffraction studies showed that $\beta$-CrPc polycrystalline powder after storage in air (RH $20 \%$ ) began to exhibit the first signs of degradation already in 1 hour, while the first changes in XRD patterns of $\alpha$-CrPc films became noticeable only after a few days. Annealing of $\alpha$-CrPc films at $250{ }^{\circ} \mathrm{C}$ in air at a relative humidity of $70 \%$ leads to their faster conversion to $\mathrm{Cr}(\mathrm{OH}) \mathrm{Pc}$, and the resulting films have a high degree of crystallinity.

Acknowledgements. The authors acknowledge the Ministry of Science and Education of the Russian Federation for a financial support.

\section{References}

1. Wöhrle D., Suvorova O., Gerdes R., Bartels O., Lapok L., Baziakina N., Makarov S., Slodek A. J. Porphyrins Phthalocyanines 2004, 8, 1020-1041.

2. Wöhrle D., Baziakina N., Suvorova O., Makarov S., Kutureva V., Schupak E., Schnurpfeil G. J. Porphyrins Phthalocyanines 2004, 8, 1390-1401.

3. Li X., De Zheng B., Peng X.H., Li S.Z., Ying J.W., Zhao Y., Huang J.D., Yoon J. Coord. Chem. Rev. 2019, 379, 147-160.

4. Sharma A.K., Mahajan A., Saini R., Bedi R.K., Kumar S., Debnath A.K., Aswal D.K. Sens. Actuators, B Chem. 2018, 255, 87-99.

5. Klyamer D., Sukhikh A., Gromilov S., Krasnov P., Basova T. Sensors 2018, 18, 2141.

6. Zhou W., Thompson J.R., Leznoff C.C., Leznoff D.B. Chem. Eur. J. 2017, 23, 2323-2331.

7. Obirai J., Nyokong T. J. Electroanal. Chem. 2004, 573, 77-85.

8. Silver J., Lukes P., Hey P., Ahmet M.T. J. Mater. Chem. 1992, 2, 841-847.

9. Ercolani C., Neri C., Porta P. Inorg. Chim. Acta 1967, 1, 415-418.

10. Shihub S.I., Gould R.D. Phys. Status Solidi 1993, 139, 129-138. 
XRD Study of Crystal Structure and Thin Films of Cr(II) Phthalocyaninate

11. Alessio P. J. Nanosci. Nanotechnol. 2012, 12, 7010-7020.

12. Schünemann C., Elschner C., Levin A.A., Levichkova M., Leo K., Riede M. Thin Solid Films 2011, 519, 3939-3945.

13. Iwatsu F., Kobayashi T., Uyeda N. J. Phys. Chem. 1980, 84, 3223-3230.

14. Takita Y., Hasegawa H., Takahashi Y., Harada J., Kanda A., Hanasaki N., Inabe T. J. Porphyrins Phthalocyanines 2014, $18,814-823$.

15. Donzello M.P., Bartolino L., Ercolani C., Rizzoli C. Inorg. Chem. 2006, 45, 6988-6995.

16. Sievertsen S., Aßmann B., Homborg H. Z. Anorg. Allg. Chem. 1996, 622, 1685-1691.

17. Myers J.F., Canham G.W.R., Lever A.B.P. Inorg. Chem. 1975, 14, 461-468.

18. Janczak J., Idemori Y.M. Inorg. Chem. 2002, 41, 5059-5065.

19. Janczak J., Idemori Y.M. Acta Crystallogr., Sect. C: Cryst. Struct. Commun. 2001, 57, 924-925.

20. APEX3, v. 2018-7.2; Bruker AXS, Inc.: Madison, Wisconsin, USA, 2018.
21. Dolomanov O.V., Bourhis L.J., Gildea R.J., Howard J.A.K., Puschmann H. J. Appl. Crystallogr. 2009, 42, 339-341.

22. Sheldrick G.M. Acta Crystallogr., Sect. A: Found. Crystal$\log r$. 2015, 71, 3-8.

23. Sheldrick G.M. Acta Crystallogr., Sect. C: Struct. Chem. 2015, 71, 3-8.

24. Brown C.J. J. Chem. Soc. A Inorg., Phys. Theor. 1968, 2488-2493.

25. Figgis B.N., Kucharski E.S., Reynolds P.A. J. Am. Chem. Soc. 1989, 111, 1683-1692.

26. Scheidt W.R., Dow W. J. Am. Chem. Soc. 1977, 99, 1101-1104.

27. Fujita K., Muto J., Itoh K.M. J. Mater. Sci. Lett. 1997, 16, 1894-1897.

28. Sukhikh A.S., Basova T.V., Gromilov S.A. Acta Phys. Pol., A 2016, 130, 889-891.

29. Sukhikh A.S., Basova T.V., Gromilov S.A. J. Struct. Chem. 2017, 58, 953-963.

30. Rodriguez-Navarro A.B. J. Appl. Crystallogr. 2006, 39, 905-909. 